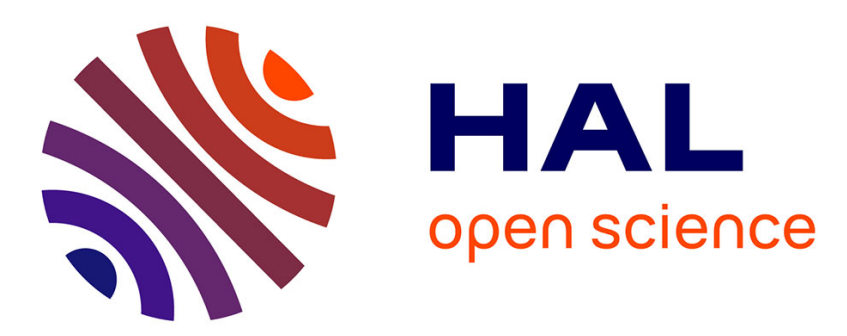

\title{
[i] Staphylococcus aureus[/i] proteins differentially produced in ewe gangrenous mastitis or ewe milk
}

Caroline Le Maréchal, Julien Jardin, Valérie Briard-Bion, Lucie Rault, Nadia Berkova, Eric Vautor, Richard Thiéry, Sergine Even, Yves Le Loir

\section{- To cite this version:}

Caroline Le Maréchal, Julien Jardin, Valérie Briard-Bion, Lucie Rault, Nadia Berkova, et al.. [i]Staphylococcus aureus[/i] proteins differentially produced in ewe gangrenous mastitis or ewe milk. Veterinary Microbiology, 2013, 164, pp.150-157. 10.1016/j.vetmic.2013.01.013 . hal-01209415

\section{HAL Id: hal-01209415 \\ https://hal.science/hal-01209415}

Submitted on 29 May 2020

HAL is a multi-disciplinary open access archive for the deposit and dissemination of scientific research documents, whether they are published or not. The documents may come from teaching and research institutions in France or abroad, or from public or private research centers.
L'archive ouverte pluridisciplinaire HAL, est destinée au dépôt et à la diffusion de documents scientifiques de niveau recherche, publiés ou non, émanant des établissements d'enseignement et de recherche français ou étrangers, des laboratoires publics ou privés. 
Short communication

\title{
Staphylococcus aureus proteins differentially produced in ewe gangrenous mastitis or ewe milk
}

\author{
Caroline Le Maréchal ${ }^{\mathrm{a}, \mathrm{b}, \mathrm{c}, 1}$, Julien Jardin ${ }^{\mathrm{a}, \mathrm{b}}$, Valérie Briard-Bion ${ }^{\mathrm{a}, \mathrm{b}}$, Lucie Rault ${ }^{\mathrm{a}, \mathrm{b}}$, \\ Nadia Berkova ${ }^{\mathrm{a}, \mathrm{b}}$, Eric Vautor ${ }^{\mathrm{c}, 2}$, Richard Thiéry ${ }^{\mathrm{c}}$, Sergine Even ${ }^{\mathrm{a}, \mathrm{b}}$, Yves Le Loir ${ }^{\mathrm{a}, \mathrm{b}, *}$ \\ ${ }^{a}$ INRA, UMR1253, Science et Technologie du Lait et de l'Euf, F-35042 Rennes, France \\ ${ }^{\mathrm{b}}$ AGROCAMPUS OUEST, UMR1253, Science et Technologie du Lait et de l'Euf, F-35042 Rennes, France \\ ${ }^{\mathrm{c}}$ ANSES, Laboratoire de Sophia-Antipolis, Unité pathologie des ruminants, F-06902 Sophia-Antipolis, France
}

\section{A R T I C L E I N F O}

\section{Article history:}

Received 10 September 2012

Received in revised form 15 January 2013

Accepted 18 January 2013

\section{Keywords:}

Proteome analysis

Gangrenous mastitis

Staphylococcus aureus

Ewe

Milk

Dairy ruminant

\begin{abstract}
A B S T R A C T
Despite being one of the main pathogens involved in ruminant mastitis, little is known about what proteins Staphylococcus aureus does express, in vivo, during the infection. Here, two $S$. aureus strains were isolated from curds formed within the udder of two ewes suffering from gangrenous mastitis. Protein samples were prepared from cell fractions and were analyzed using 1D-LC MS/MS. Results were compared to 1D-LC MS/MS analysis of the same $S$. aureus strains grown in ewe milk. A total of 365 proteins were identified. Most of them were related to cellular metabolism, cellular division and stress response. Half of the proteins were found in both conditions but a substantial number were specifically found in in vivo conditions and gave indications about the active metabolic status and the stresses encountered by $S$. aureus within the cistern during a gangrenous mastitis.
\end{abstract}

(c) 2013 Elsevier B.V. All rights reserved.

\section{Introduction}

Despite great research efforts, mastitis remains a major concern for dairy ruminant herds worldwide. It causes huge economic losses and affects animal health as well as milk quality (Le Maréchal et al., 2011c). Investigation of Staphylococcus aureus transcriptome or proteome in vivo stumbles on technical bottlenecks such as the difficulty to localize the infection site within the udder and the low amounts of $S$. aureus cells that can be recovered from such infections. Serological proteome analysis (SERPA) was

\footnotetext{
* Corresponding author at: INRA, UMR1253, Science et Technologie du Lait et de l'Euf, F-35042 Rennes, France.

E-mail address: Yves.LeLoir@rennes.inra.fr (Y. Le Loir).

1 Present address: ANSES, Laboratoire de Ploufragan Plouzané, Unité Hygiène et Qualité des Produits Avicoles et Porcins, F-22000 Ploufragan, France.

2 Present address: Laboratoire vétérinaire départemental des AlpesMaritimes, F-06902, Sophia-Antipolis, France.
}

recently used to circumvent these difficulties (Le Maréchal et al., 2011d; Tedeschi et al., 2009). It allows investigating the $S$. aureus proteins recognized by the host's immune response and thus identifying proteins that are indeed produced by $S$. aureus during mastitis. However, such identification is restricted to the immune reactive proteins and does not shed light on other non immune reactive proteins that can nevertheless be produced during infection. Recent advances in proteomics (namely, GeLC-MS/MS) allow discovering proteins from complex samples containing low amounts of proteins. The objective of this work was to identify the proteins that are differentially produced in bacterial cells or tightly cellbound when $S$. aureus grows in gangrenous mastitis conditions compared to growth in the same milk medium but in laboratory conditions. A better inventory of the proteins produced by $S$. aureus, strains whatever their degree of virulence during the mastitis onset may indeed help understanding pathways important for mastitis pathogenesis. 


\section{Materials and methods}

\subsection{Bacterial strains, growth conditions and protein extraction}

S. aureus strains 011 and 046 are two clonally related strains originally isolated from gangrenous and subclinical ewe mastitis cases, respectively (Vautor et al., 2009). In vivo samples analyzed in the present study were obtained from animals experimentally infected in an $S$. aureus challenge study conducted at the French National Agency for Food, Environmental and Occupational Health and Safety (Le Maréchal et al., 2011d) and according to the Regional Committee for Animal Use and Care (Côte d'Azur, France), recorded under reference NCA/2008-14/12-09n. In this previous experiment, two ewes developed a gangrenous mastitis (one after being inoculated by strain 011 and one by strain 046) shortly after infection. Such sudden onset of a severe infection sometimes occurs in small ruminants (Cetin et al., 2005; Le Maréchal et al., 2011d; Rainard, 2007) and the two suffering ewes were humanely euthanized $24 \mathrm{~h}$ post-infection. Coagulated milk was then aseptically collected from the cistern and stored at $-80{ }^{\circ} \mathrm{C}$. Bacteria extraction was performed as previously described (Cretenet et al., 2011). Briefly, to harvest bacteria, $10 \mathrm{~g}$ of in situ coagulated milk were homogenized with $90 \mathrm{~mL}$ of trisodium citrate solution (2\% $(\mathrm{w} / \mathrm{v}))$ at $4{ }^{\circ} \mathrm{C}$ using a mechanical Waring blender. Three 30-s mixing sequences were performed at high speed, and three 10-s mixing sequences performed at low speed. Cells from $10 \mathrm{~mL}$ of suspension were then recovered by centrifugation for $5 \mathrm{~min}$ at $6000 \times \mathrm{g}$ at $4{ }^{\circ} \mathrm{C}$. These steps allowed removing most of the milk proteins, which abundance could interfere with the identification of bacterial proteins. In vitro samples were obtained after incubation of an overnight culture of strain 011 and strain O46 in BHI diluted 1:1000 in $100 \mathrm{~mL}$ of semi-skimmed ewe milk at $37{ }^{\circ} \mathrm{C}$ without agitation during $24 \mathrm{~h}$ (the same time lapse as in the ewe mammary gland). Bacteria were harvested as described above. After washing in ice-cold PBS, total lysates were prepared using lysostaphin treatment and sonication. The lysates were centrifuged to obtain the bacterial protein extracts (Le Maréchal et al., 2009).

\subsection{GeLC-MS/MS analysis}

Protein extracts were separated by SDS-PAGE on $12 \%$ acrylamide separating slab gels with a $4 \%$ acrylamide stacking gel on a Protean II gel system (BioRad, Ivry sur Seine, France). Migration was performed overnight at room temperature under a constant $60 \mathrm{~V}$ voltage. Samples were diluted in $45 \mu \mathrm{L}$ of sample buffer and denatured at $100{ }^{\circ} \mathrm{C}$ for $3 \mathrm{~min}$. Gels were stained with Coomassie blue R-250. Each lane was manually cut into slices and transferred into $0.5 \mathrm{~mL}$ eppendorfs. After washing with acetonitrile, proteins were reduced ( $10 \mathrm{mM}$ DTT), then alkylated (55 mM iodoacetamide) and finally dried under vacuum in a SpeedVac concentrator (SVC100H-200; Savant, Thermo Fisher Scientific, Waltham, MA, USA). In-gel trypsin digestion was performed overnight at $37^{\circ} \mathrm{C}$ and stopped with spectrophotometric-grade trifluoroacetic acid (TFA) (Sigma-Aldrich).

Nano-LC experiments were performed on the supernatants using an on-line liquid chromatography tandem mass spectrometry (MS/MS) setup using a Dionex U3000RSLC nano-LC system fitted to a QSTAR XL (MDS SCIEX, Ontario, Canada) equipped with a micro-electrospray ion source (ESI) (Proxeon Biosystems A/S, Odense, Denmark). Samples were first concentrated on a PepMap 100 reversephase column (C18, $5 \mu \mathrm{m}, 300-\mu \mathrm{m}$ inner diameter (i.d.) by $5 \mathrm{~mm}$ length) (Dionex, Amsterdam, The Netherlands). Peptides were separated on a reverse phase PepMap column (C18, $3 \mu \mathrm{m}, 75 \mu \mathrm{m}$ i.d. by $150 \mathrm{~mm}$ length) (Dionex) at $35^{\circ} \mathrm{C}$, using solvent $\mathrm{A}(2 \%$ (vol/vol) acetonitrile, $0.08 \%$ ( $\mathrm{vol} / \mathrm{vol}$ ) formic acid, and $0.01 \%$ ( $\mathrm{vol} / \mathrm{vol}$ ) TFA in deionized water) and solvent B (95\% ( vol/vol) acetonitrile, $0.08 \%$ (vol $/ \mathrm{vol}$ ) formic acid, and $0.01 \%$ ( $\mathrm{vol} / \mathrm{vol}$ ) TFA in deionized water). A linear gradient from 10 to $40 \%$ of solvent B in 45 min was applied for the elution at a flow rate of $0.3 \mu \mathrm{L} / \mathrm{min}$. Eluted peptides were directly electrosprayed into the mass spectrometer operated in positive mode. A full continuous MS scan was carried out followed by three data-dependent MS/MS scans. Spectra were collected in the selected mass range $400-2000 \mathrm{~m} / \mathrm{z}$ for MS and $60-2000 \mathrm{~m} / \mathrm{z}$ for MS/MS spectra. The three most intense ions from the MS scan were selected individually for collision-induced dissociation (1+ to 4+ charged ions were considered for the MS/MS analysis). The mass spectrometer was operated in data-dependent mode automatically switching between MS and MS/MS acquisition using Analyst QS 1.1 software. The instrument was calibrated by multipoint calibration using fragment ions that resulted from the collision-induced decomposition of a peptide from $\beta$-casein, $\beta$-CN (193-209). The proteins present in the samples were identified from MS and MS/MS data using MASCOT v.2.2 software for search into two concatenated databases: (i) a homemade database containing all the predicted proteins of the $S$. aureus strains 011 and 046 used in this study and (ii) a portion of the UniProtKB database corresponding to the $S$. aureus taxonomic group. Search parameters were set as follows. A trypsin enzyme cleavage was used, the peptide mass tolerance was set to 0.2 Da for both MS and MS/MS spectra, and two variable modifications (oxidation of methionine and deamidation of asparagine and glutamine residues) were selected. A maximum of one missed tryptic cleavage site was allowed. For each protein identified in NanoLCESI-MS/MS, a minimum of two peptides with MASCOT score corresponding to a $p$-value below 0.05 were necessary for validation of the protein. For automatic validation of the peptides from MASCOT search results, the 1.19.2 version of the IRMa software was used (Dupierris et al., 2009).

\section{Results and discussion}

In situ study of pathogens is tricky but really informative to better understand the infectious processes. In contrast to Escherichia coli mastitis, severity of S. aureus mastitis depends on strain-specific rather than on hostspecific characteristics (Burvenich et al., 2003; Haveri et al., 
2007; Le Maréchal et al., 2011b). However, in some cases, the health status of individual animals (e.g. transient weakness, immunodeficiency, other infection, etc.) may lead to the onset of severe symptoms even when the infection involves an $S$. aureus strain like 046 that reportedly induces mild mastitis (Le Maréchal et al., 2011d). The two mastitis cases used in this work were two severe gangrenous mastitis cases with a sudden onset ( $24 \mathrm{~h}$ post-infection), each of which resulted from an experimental infection with two $S$. aureus strains. Investigating the proteome of these two different strains might help discovering what $S$. aureus has to cope with during the onset of a gangrenous mastitis, beyond any strain specific features. Here, we report the first proteome analysis of bacteria extracted from curds resulting from the intramammary coagulation of cisternal milk after gangrenous mastitis. Using 1D-LC MS/MS, we managed to identify 365 proteins, which were produced during gangrenous ewe mastitis by strain 011 or 046 , two $S$. aureus strains isolated from mastitis and fully characterized (Le Maréchal et al., 2011a, 2011b, 2011d) (Table S1, supplemental data).

Supplementary data associated with this article can be found, in the online version, at http://dx.doi.org/10.1016/ j.vetmic.2013.01.013.

Substantial differences were observed when considering each of the two strains. A pool of 242 proteins was found common to strain 011 and 046 grown in vitro or in vivo, whereas 39 were strain 011-specific, and 80 were strain 046-specific (Fig. 1A). Some strain 011-specific proteins identified here were previously shown overproduced in 011 (e.g. LukM and LukF-PV), compared to strain 046 (Le Maréchal et al., 2011b). On the other hand, the gene encoding SpoVG, a strain O46-specific protein, was previously shown to be truncated in strain 011 (Le Maréchal et al., 2011b).

The most apparent differences were observed when considering the in vitro or in vivo growth conditions. Under both growth conditions 187 proteins were produced, in

A

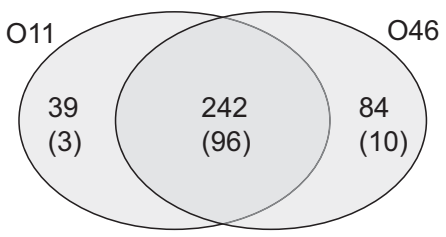

B

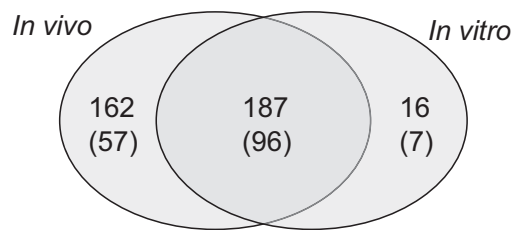

Fig. 1. (A) Venn diagram summarizing strain 011- and 046-specific proteins. Some proteins were found in strain 011 or 046 samples, only. In between parentheses, the number of proteins found common in both in vitro and in vivo conditions. (B) Venn diagram summarizing the gangrenous mastitis- and milk-specific S. aureus proteins. In total, 365 proteins were identified, some of which were found in gangrenous mastitis samples or milk samples, only. In between parentheses, the number of proteins found common in both 011 and 046 strains. one strain or the other (Fig. 1B). Ninety six of these proteins $(\sim 31 \%)$ were identified in both in vivo and in vitro samples and in both strains. They include numerous proteins involved in central metabolism and pathways that are likely necessary to support bacterial growth whatever the conditions. Some proteins, such as LacD, LacE, LacG and Ldh reflect adaptation to the milk environment found in both growth conditions (Table S1).

Of 365 proteins in total identified under either or both growth conditions, 35 belong to the set of 89 proteins that were previously shown to be produced during mastitis using serological proteome analysis (Table 1). A majority (32 proteins) was previously found immunoreactive in both strains (core seroproteome) whereas 3 were strain 011-specific (accessory proteome). Production of LukF'-PV was confirmed to be produced by strain 011 only. This protein has been reported to be associated with strains isolated from gangrenous mastitis in small ruminants (Le Maréchal et al., 2011d; Rainard, 2007). However, it appears here that 046 , for which no production of LukF'-PV was detected, can nevertheless induce a gangrenous mastitis suggesting that other factors (likely host factors, here) are involved in the sudden onset of severe mastitis. On the contrary, we were not able to detect other well characterized virulence factors, which were previously shown to be produced during mastitis (Le Maréchal et al., 2011d). These proteins might have been eliminated during samples preparation since, to minimize contamination with milk proteins, cell pellets were washed prior to protein extraction.

Among the 35 reportedly immune reactive proteins identified, 20 proteins (57\%) were identified on the basis of a high number of peptides (above 10 peptides) with 10 proteins being identified on the basis of more than 20 peptides, namely, bifunctional acetaldehyde-CoA/alcohol dehydrogenase (42 and 39 peptides for strain 011 and 046 , respectively, in gangrenous curd), formate acetyltransferase (36/41), Fda (21/22), enolase (22/24), elongation factor Tsf (21/20), and elongation factor G Fus (28/24), RpoB (27/ $40)$, RpoC (41/53), ClpC (17/23), and probable malate:quinone oxidoreductase 1 (19/20).

Some of these proteins are known to be moonlighting proteins, i.e. they have different functions depending on their localization. For example, GAPDH and enolase have been shown to play a role in adhesion when surface exposed (Antikainen et al., 2007; Pancholi and Chhatwal, 2003).

Most proteins identified in S. aureus strains isolated from the gangrenous curd belong to functional categories in relation with cellular metabolism (Fig. 2). The presence of RpoB and RpoC (two RNA polymerases; Table 1) suggests an active metabolism of $S$. aureus within the mammary gland during acute infection. Proteins involved in cell division were also present (FtsZ, EzrA), which may also indicate bacterial multiplication within the curd.

Besides, several stress related proteins were also identified, including chaperones such as DnaK, GroEL, Clp proteins, detoxifying enzymes, such as superoxide dismutases (SodA and SodM), reductases (AhpC, AhpF and TrxB), UreE, and putative universal stress protein, showing that the conditions encountered by $S$. aureus in the 
Table 1

Proteins identified in this study that were previously shown immunoreactive.

\begin{tabular}{|c|c|c|c|c|c|c|c|c|c|}
\hline Description $^{\mathrm{a}}$ & Accession $^{\mathrm{b}}$ & Gene name $^{\mathrm{c}}$ & O11 ${ }^{\mathrm{d}}$ & O46 & SERPA $^{\mathrm{f}}$ & $\begin{array}{l}\text { No. of } \\
\text { peptides } \\
\text { O11 curd }\end{array}$ & $\begin{array}{l}\text { No. of peptides } \\
\text { O46 } \text { curd }^{\mathrm{h}}\end{array}$ & $\begin{array}{l}\text { No. of } \\
\text { peptides } \\
\text { O11 milk }\end{array}$ & $\begin{array}{l}\text { No. of } \\
\text { peptides } \\
\text { O46 milk }\end{array}$ \\
\hline \multicolumn{10}{|l|}{ Energy production and conversion } \\
\hline L-lactate dehydrogenase 1 & F0D325_STAAU & ldh & SA011_0603 & SAO46_0550 & $\mathrm{X}(\mathrm{0} 11)$ & 13 & 13 & 6 & 9 \\
\hline Bifunctional acetaldehyde-CoA/alcohol dehydrogenase & FOD3T4_STAAU & & SA011_0863 & SAO46_0494 & $\mathrm{X}$ (core) & 42 & 39 & 16 & 34 \\
\hline Formate acetyltransferase & FOD407_STAAU & & SA011_0936 & SAO46_0593 & $\mathrm{X}$ (core) & 36 & 41 & 26 & 35 \\
\hline \multicolumn{10}{|l|}{ Cell cycle control and mitosis } \\
\hline Cell division protein $\mathrm{ftsZ}$ & F0D1E9_STAAU & $\mathrm{ftsZ}$ & SA011_0025 & SAO46_1757 & & 12 & 7 & 8 & 14 \\
\hline Septation ring formation regulator EzrA & FOD2F9_STAAU & ezrA & SAO11_0386 & SAO46_1105 & & 16 & 11 & 4 & 12 \\
\hline \multicolumn{10}{|l|}{ Nucleotide metabolism and transport } \\
\hline Adenylate kinase & FOD4J7_STAAU & adk & SA011_1227 & SAO46_1328 & $\mathrm{X}$ (core) & 2 & 3 & & 1 \\
\hline Purine nucleoside phosphorylase deoD-type 2 & F0D6F7_STAAU & deoD & SA011_1788 & SAO46_1651 & $\mathrm{X}$ (core) & 2 & 3 & 2 & 2 \\
\hline Inosine-5'-monophosphate dehydrogenase & F0D6Q0_STAAU & guaB & SAO11_1881 & SAO46_1449 & $\mathrm{X}$ (core) & 18 & 19 & 10 & 15 \\
\hline \multicolumn{10}{|l|}{ Carbohydrate metabolism and transport } \\
\hline Fructose-diphosphate aldolase class 1 & FOD320_STAAU & $\mathrm{fda}$ & SA011_0598 & SAO46_0554 & $\mathrm{X}$ (core) & 21 & 22 & 12 & 20 \\
\hline $\begin{array}{l}\text { 2,3-bisphosphoglycerate-dependent } \\
\text { phosphoglycerate mutase }\end{array}$ & F0D5Q2_STAAU & gpmA & SAO11_1532 & SAO46_1391 & $\mathrm{X}$ (core) & 5 & 12 & & 1 \\
\hline Glyceraldehyde-3-phosphate dehydrogenase & F0D8I7_STAAU & gap & SA011_2520 & SAO46_2072 & $\mathrm{X}$ (core) & 17 & 16 & 9 & 14 \\
\hline Triosephosphate isomerase & F0DF58_STAAU & tpiA & SA011_2522 & SAO46_2074 & $\mathrm{X}$ (core) & 11 & 12 & 6 & 8 \\
\hline Enolase & F0D8J1_STAAU & eno & SAO11_2524 & SAO46_2076 & $\mathrm{X}$ (core) & 22 & 24 & 18 & 19 \\
\hline \multicolumn{10}{|l|}{ Lipid metabolism } \\
\hline $\begin{array}{l}\text { (3R)-hydroxymyristoyl-[acyl- } \\
\text { carrier-protein] dehydratase }\end{array}$ & F0D6M2_STAAU & fabZ & SAO11_1853 & SAO46_1611 & $\mathrm{X}$ (core) & 2 & & & \\
\hline Acetoin reductase & FOD3K9_STAAU & & SA011_0787 & SAO46_0963 & $\mathrm{X}$ (core) & 10 & 10 & 6 & 6 \\
\hline \multicolumn{10}{|l|}{ Translation } \\
\hline Elongation factor Ts & F0D1M7_STAAU & tsf & SA011_0103 & SAO46_0015 & $\mathrm{X}$ (core) & 21 & 20 & 9 & 16 \\
\hline 30 S ribosomal protein $\mathrm{S} 4$ & FOD2F7_STAAU & rpsD & SAO11_0384 & SAO46_1103 & $\mathrm{X}$ (core) & 14 & 10 & 7 & 5 \\
\hline Elongation factor $\mathrm{P}$ & F0D3E4_STAAU & efp & SA011_0722 & SAO46_0849 & $\mathrm{X}$ (core) & 3 & 4 & & \\
\hline 50 S ribosomal protein $\mathrm{L} 3$ & F0D4H6_STAAU & $\mathrm{rplC}$ & SA011_1206 & SAO46_1307 & $\mathrm{X}$ (core) & 7 & 2 & 5 & 7 \\
\hline Elongation factor $\mathrm{G}$ & F0D596_STAAU & fus & SAO11_1375 & SAO46_0988 & $\mathrm{X}$ (core) & 28 & 24 & 15 & 31 \\
\hline Elongation factor $\mathrm{Tu}$ & F0D597_STAAU & tuf & SA011_1376 & SAO46_0987 & $\mathrm{X}$ (core) & 19 & 15 & 16 & 20 \\
\hline $30 \mathrm{~S}$ ribosomal protein $\mathrm{S} 1$ & F0D625_STAAU & rp & SA011_1656 & SAO46_1856 & $\mathrm{X}$ (core) & 19 & 14 & 12 & 16 \\
\hline 50S ribosomal protein L25 & FOD893_STAAU & rplY & SA011_2426 & SAO46_2014 & $\mathrm{X}$ (core) & 5 & 6 & 5 & 4 \\
\hline \multicolumn{10}{|l|}{ Transcription } \\
\hline GTP-sensing transcriptional pleiotropic repressor CodY & F0D1M4_STAAU & $\operatorname{cod} Y$ & SA011_0100 & SAO46_0012 & & 12 & 11 & 4 & 7 \\
\hline DNA-directed RNA polymerase subunit beta & F0D591_STAAU & гров & SAO11_1370 & SAO46_0993 & & 27 & 40 & 5 & 24 \\
\hline $\begin{array}{l}\text { DNA-directed RNA polymerase subunit } \beta^{\prime} \\
\text { Replication and repair }\end{array}$ & F0D592_STAAU & rpoC & SAO11_1371 & SAO46_0992 & & 41 & 53 & 1 & 47 \\
\hline \multicolumn{10}{|l|}{ Replication and repair } \\
\hline \multirow{2}{*}{\multicolumn{10}{|c|}{ Cell wall/membrane/envelop biogenesis }} \\
\hline & & & & & & & & & \\
\hline Putative septation protein spoVG & F0D890_STAAU & spoVG & SA011_2423 & SAO46_2017 & & & 2 & & \\
\hline \multicolumn{10}{|c|}{ Post-translational modification, protein turnover, chaperone functions } \\
\hline Putative ATP-dependent protease protein & FODA01_STAAU & $\mathrm{clpB}$ & SA011_0300 & SAO46_0263 & & 7 & 7 & & \\
\hline Trigger factor & FOD2K1_STAAU & tig & SAO11_0428 & SAO46_1149 & $\mathrm{X}$ (core) & 14 & 16 & 12 & 15 \\
\hline ATP-dependent proteinase chain & F0D379_STAAU & clpL & SA011_0657 & SAO46_1215 & & 4 & 14 & 4 & 18 \\
\hline Urease accessory protein ureE & FODAE9_STAAU & ureE & SAO11_1165 & SAO46_0411 & & & 3 & & \\
\hline $60 \mathrm{kDa}$ chaperonin & F0D531_STAAU & groEL & SA011_1310 & SAO46_1078 & & 19 & 18 & 1 & 3 \\
\hline Endopeptidase & FOD573_STAAU & $\mathrm{clpC}$ & SAO11_1352 & SAO46_1011 & & 17 & 23 & & \\
\hline Alkyl hydroperoxide reductase subunit C & F0D6Q8_STAAU & ahpC & SA011_1889 & SAO46_1458 & $\mathrm{X}$ (core) & 2 & 5 & 4 & 2 \\
\hline Alkyl hydroperoxide reductase subunit $F$ & FODDE3_STAAU & ahpF & SAO11_1890 & SAO46_1459 & $\mathrm{X}(011)$ & & 8 & & 4 \\
\hline
\end{tabular}




\begin{tabular}{|c|c|c|c|c|c|c|c|c|c|}
\hline Description $^{\mathrm{a}}$ & Accession $^{\mathrm{b}}$ & Gene name ${ }^{\mathrm{c}}$ & $011^{d}$ & $046^{\mathrm{e}}$ & SERPA $^{\mathrm{f}}$ & $\begin{array}{l}\text { No. of } \\
\text { peptides } \\
\text { O11 curd }\end{array}$ & $\begin{array}{l}\text { No. of peptides } \\
\text { O46 } \text { curd }^{\mathrm{h}}\end{array}$ & $\begin{array}{l}\text { No. of } \\
\text { peptides } \\
\text { O11 milk }\end{array}$ & $\begin{array}{l}\text { No. of } \\
\text { peptides } \\
\text { O46 milk }\end{array}$ \\
\hline Thioredoxin reductase & F0D8B3_STAAU & $\operatorname{trxB}$ & SAO11_2446 & SAO46_2742 & $\mathrm{X}(011)$ & 6 & 8 & & 5 \\
\hline Molecular chaperone DnaK (Fragment) & F0D8Q4_STAAU & dnaK & SAO11_2587 & SAO46_2761 & $\mathrm{X}$ (core) & 7 & 6 & 3 & 3 \\
\hline \multicolumn{3}{|l|}{ Inorganic ion transport and metabolism } & SA011_2515 & SAO46_2067 & & & 3 & 1 & \\
\hline Superoxide dismutase & F0D3G9_STAAU & sodA & SAO11_0747 & SAO46_0874 & & 2 & 10 & 2 & 2 \\
\hline Superoxide dismutase & FOD3K3_STAAU & sodM & SAO11_0781 & SAO46_0969 & & 4 & 8 & 2 & \\
\hline Iron-repressed lipoprotein & F0D698_STAAU & $\mathrm{mntC}$ & SAO11_1707 & SAO46_1927 & $\mathrm{X}$ (core) & 17 & 11 & & 4 \\
\hline \multicolumn{10}{|l|}{ General functional prediction only } \\
\hline Probable malate:quinone oxidoreductase 1 & F0D319_STAAU & mqo & SAO11_0597 & SAO46_0330 & $\mathrm{X}$ (core) & 19 & 20 & 7 & 13 \\
\hline Alcohol dehydrogenase & F0D6C2_STAAU & adhA & SAO11_1731 & SAO46_1951 & $\mathrm{X}$ (core) & 17 & 16 & 11 & 14 \\
\hline \multicolumn{10}{|l|}{ Signal transduction } \\
\hline Putative universal stress protein & F0D2H1_STAAU & & SAO11_0398 & SAO46_1117 & $\mathrm{X}$ (core) & 3 & & 1 & \\
\hline Respiratory response protein, SrrA & F0D610_STAAU & srrA & SAO11_1641 & SAO46_2509 & & 5 & 4 & & \\
\hline \multicolumn{10}{|l|}{ Virulence-defense mechanism } \\
\hline Leukocidin chain lukM & F0D7A7_STAAU & & SAO11_2088 & SAO46_2661 & $\mathrm{X}$ (core) & 2 & & & \\
\hline Panton-Valentine leukocidin LukF-PV chain & FOD7A8_STAAU & & SAO11_2089 & SAO46_2662 & $\mathrm{X}$ (core) & 2 & & & \\
\hline \multicolumn{10}{|l|}{ Unknown function } \\
\hline Ribosomal subunit interface protein (fragment) & F0D7N5_STAAU & yfiA & SAO11_2217 & SAO46_2753 & $\mathrm{X}$ (core) & 3 & 5 & 2 & 3 \\
\hline Peptidyl-prolyl cis-isomerase (fragment) & FOD8V0_STAAU & & SAO11_2633 & SAO46_2695 & $\mathrm{X}$ (core) & 3 & & & \\
\hline Alkaline shock protein 23 & F0D8G3_STAAU & asp23 & SAO11_2496 & SAO46_2306 & & 5 & 5 & & \\
\hline
\end{tabular}

a Proteins are classified in Gene Ontology functional classes. Names are given according to annotation of available $S$. aureus sequence genomes.

b Accession number on Uniprot.

c Gene name.

d Coding sequence numbers corresponding to the identified proteins in S. aureus 011

e Coding sequence numbers corresponding to the identified proteins in S. aureus 046 .

Also identified in Le Maréchal et al. (2011d). Proteins belonging to the core seroproteome (core) and 011 accessory seroproteome (011) are indicated.

$\mathrm{g}$ Number of peptides identified in sample from curd isolated after infection by 011.

h Number of peptides identified in sample from curd isolated after infection by 046.

${ }^{i}$ Number of peptides identified in sample from 011 grown in vitro in ewe milk.

j Number of peptides identified in sample from 046 grown in vitro in ewe milk. 


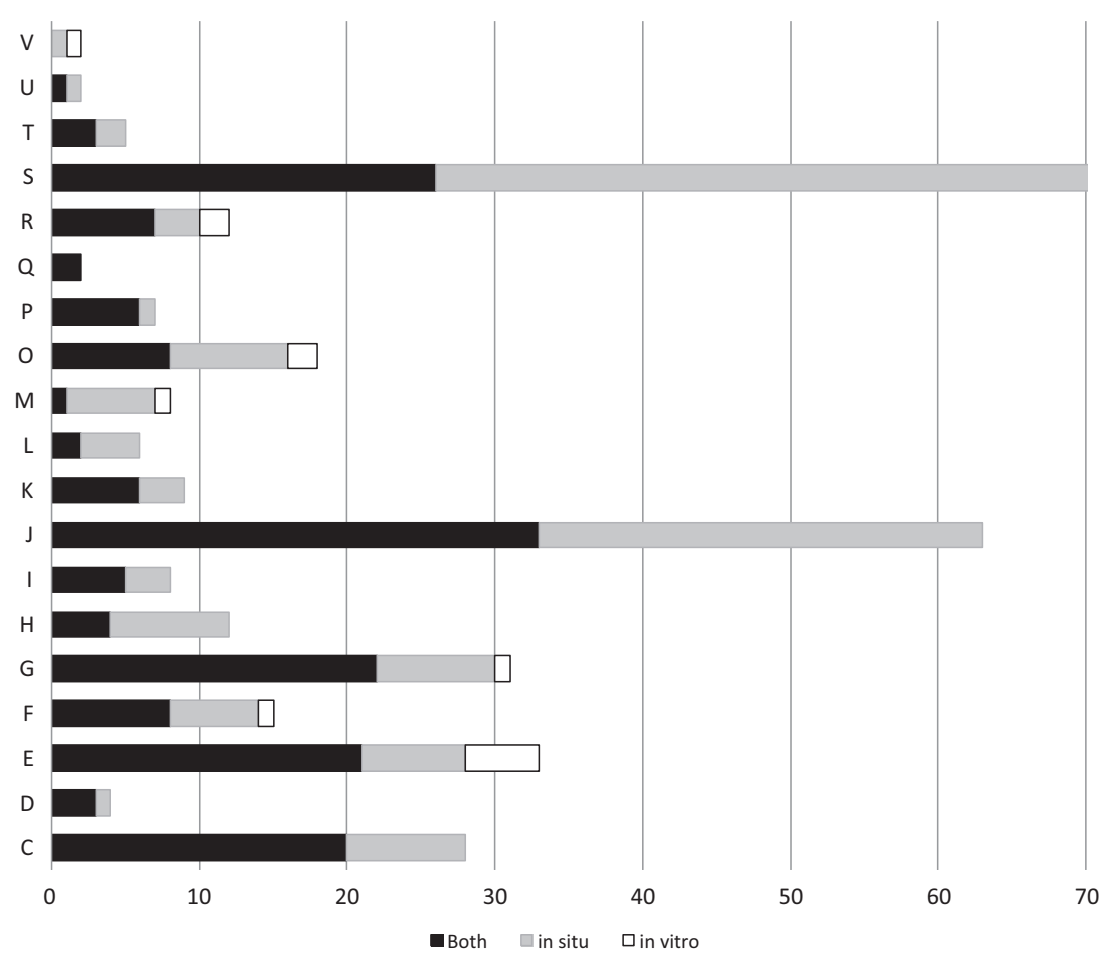

Fig. 2. Number of proteins identified in this study per functional categories. Proteins found in both conditions (milk and gangrenous curd) are in black, found only in the gangrenous curd are in grey and only found in milk are in white. C: Energy production and conversion, D: cell cycle control and mitosis, E: amino acid metabolism and transport, F: nucleotide metabolism and transport, G: carbohydrate metabolism and transport, H: coenzyme metabolism, I: lipid metabolism, J: translation, K: transcription, L: replication and repair, M: cell wall/membrane/envelop biogenesis, O: post-translational modification, protein turnover, chaperone functions, P: inorganic ion transport and metabolism, Q: secondary structure, R: general functional prediction only, S: function unknown, T: signal transduction, U: intracellular trafficking and secretion, and V: virulence and defense mechanism. See Table S1 for details.

gangrenous mastitis context are somehow stressful. Several regulators which expression have been shown to be linked to environmental conditions were also detected. SpoVG, SarA and Asp23 are part of sigmaB regulon (Bischoff et al., 2004; Chan et al., 1998; Kullik et al., 1998; Kullik and Giachino, 1997). SigmaB is involved in the regulation of many cellular processes, including stress responses, intermediary metabolism and virulence and is induced under environmental stresses (Bischoff et al., 2004; Chan et al., 1998). It is well-known that oxygen level is very low in the mammary gland especially during mastitis (Mayer et al., 1988). SrrA, which plays a role in gene regulation under anaerobic conditions (Fuchs et al., 2007), was detected in in vivo samples. Its production may be linked to low oxygen conditions found during mastitis. Finally, we also detected CodY in in vivo samples, a regulator involved in the adaptation response to starvation (Stenz et al., 2011). Detection of these regulators is particularly informative for understanding infection process. They are indeed indicators of the stressful conditions encountered in gangrenous mastitis context, which include low oxygen availability and starvation. Besides, these regulators are involved in the regulation of expression of virulence factors which may have a preponderant role in symptoms observed during gangrenous mastitis.

Milk or whey is currently considered the best media to mimic the conditions bacteria encounter in the first steps of intramammary infection (Lammers et al., 2000). Growth in milk or whey was shown to induce the production of anti-phagocytic surface properties (Mamo et al., 1991b) and in vivo-like antigens (Mamo and Froman, 1994b), the virulence of $S$. aureus (Mamo et al., 1991a), and the adhesion of $S$. aureus to bovine mammary epithelial cells (Mamo and Froman, 1994a). However, we previously showed that deferroxamine-RPMI (a cell culture medium) could be considered as a good model medium as well (Le Maréchal et al., 2009). In this study, curd was sampled from the mammary gland of ewes. Ewe milk was thus thought to be more relevant than RPMI to be used as an in vitro reference medium. Growth in milk allowed the induction of most of the same metabolic pathways and some of the stress-induced proteins as illustrated in Fig. 2, but did not totally mimic conditions found in the udder cistern. In particular, higher numbers of proteins were found in $S$. aureus grown under in vivo conditions compared to bacteria grown under in vitro conditions. These proteins were mostly involved in replication and repair (4 proteins were identified in in vivo and not in vitro growth conditions out of the 6 herein identified proteins belonging to this Gene Ontology Functional class), signal transduction ( 2 proteins identified in in vivo and not in vitro growth conditions out of 5 herein identified proteins belonging to this Gene Ontology Functional class) and post-translational modifications ( 9 proteins identified in in 
vivo and not in vitro growth conditions out of 17 herein identified proteins belonging to this Gene Ontology Functional class) (Table S1). These observations suggest that bacteria are actively multiplying in the cistern, but not in milk $24 \mathrm{~h}$ post infection and post inoculation. The differences observed might result from different growth rates in the in vivo and the in vitro conditions and/or from the absence of immune response, which might trigger $S$. aureus responses when growing under in vivo conditions. They however reflect that growth in milk without agitation does not completely mimic cistern conditions.

Altogether these results give information about what $S$. aureus can produce during gangrenous mastitis. Most proteins that were found differentially produced in gangrenous context versus laboratory conditions were found common to both strains. As results presented here are based on a single in vivo experiment, one might keep in mind that some of the proteins identified here were strainspecific and that, by extension, different proteomic profiles (especially in terms of accessory proteome) may result from similar experiments with other $S$. aureus mastitis isolates. Recent studies attempted to identify pathogens' proteome in vivo in animal or human pathogens (Hughes et al., 2007; Kruh et al., 2010; Kuntumalla et al., 2011; Sengupta and Alam, 2011). S. aureus cell fractions were analyzed here and thus many of the secreted virulence factors known to be involved in pathogenesis could not be detected. A majority of the proteins identified was assigned to functional categories such as energy production and conversion, amino acid metabolism and transport, carbohydrate metabolism and transport, and translation. Their presence in mastitis samples showed that $S$. aureus is metabolically active during acute mastitis and has to tackle stress, starvation and low oxygen. Growth in milk with no aeration during $24 \mathrm{~h}$ seems to partially mimic in vivo conditions but is not fully satisfactory.

\section{Acknowledgments}

Caroline Le Maréchal was the recipient of a $\mathrm{PhD}$ grant from the Institut National de la Recherche Agronomique (INRA) and the Agence Nationale de Sécurité Sanitaire (ANSES), IMISa Project. Coralie Pulido and Jean-Michel Guibert are greatfully acknowledged for handling experimental ewes.

\section{References}

Antikainen, J., Kuparinen, V., Lahteenmaki, K., Korhonen, T.K., 2007. Enolases from Gram-positive bacterial pathogens and commensal lactobacilli share functional similarity in virulence-associated traits. FEMS Immunol. Med. Microbiol. 51, 526-534.

Bischoff, M., Dunman, P., Kormanec, J., Macapagal, D., Murphy, E., Mounts, W., Berger-Bachi, B., Projan, S., 2004. Microarray-based analysis of the Staphylococcus aureus sigmaB regulon. J. Bacteriol. 186, 4085-4099.

Burvenich, C., Van, M.V., Mehrzad, J., ez-Fraile, A., Duchateau, L., 2003. Severity of E. coli mastitis is mainly determined by cow factors. Vet. Res. 34, 521-564.

Cetin, H., Yaralioglu Gurgoze, S., Keskin, O., Atli, M.O., Korkmaz, O., 2005. Investigation of antioxidant enzymes and some biochemical parameters in ewes with gangrenous mastitis. Turk. J. Vet. Anim. Sci. 29, 303-308.

Chan, P.F., Foster, S.J., Ingham, E., Clements, M.O., 1998. The Staphylococcus aureus alternative sigma factor sigmaB controls the environmental stress response but not starvation survival or pathogenicity in a mouse abscess model. J. Bacteriol. 180, 6082-6089.

Cretenet, M., Nouaille, S., Thouin, J., Rault, L., Stenz, L., Francois, P., Hennekinne, J.A., Piot, M., Maillard, M.B., Fauquant, J., Loubiere, P. Le Loir, Y., Even, S., 2011. Staphylococcus aureus virulence and metabolism are dramatically affected by Lactococcus lactis in cheese matrix. Environ. Microbiol. Reports 3, 340-351.

Dupierris, V., Masselon, C., Court, M., Kieffer-Jaquinod, S., Bruley, C., 2009. A toolbox for validation of mass spectrometry peptides identification and generation of database: IRMa. Bioinformatics 25, 1980-1981.

Fuchs, S., Pane-Farre, J., Kohler, C., Hecker, M., Engelmann, S., 2007. Anaerobic gene expression in Staphylococcus aureus. J. Bacteriol. 189, 4275-4289.

Haveri, M., Roslof, A., Rantala, L., Pyorala, S., 2007. Virulence genes of bovine Staphylococcus aureus from persistent and nonpersistent intramammary infections with different clinical characteristics. J. Appl. Microbiol. 103, 993-1000.

Hughes, V., Smith, S., Garcia-Sanchez, A., Sales, J., Stevenson, K., 2007 Proteomic comparison of Mycobacterium avium subspecies paratuberculosis grown in vitro and isolated from clinical cases of ovine paratuberculosis. Microbiology 153, 196-205.

Kruh, N.A., Troudt, J., Izzo, A., Prenni, J., Dobos, K.M., 2010. Portrait of a pathogen: the Mycobacterium tuberculosis proteome in vivo. PLoS ONE 5, e13938.

Kullik, I.I., Giachino, P., 1997. The alternative sigma factor sigmaB in Staphylococcus aureus: regulation of the $\operatorname{sig} B$ operon in response to growth phase and heat shock. Arch. Microbiol. 167, 151-159.

Kullik, I., Giachino, P., Fuchs, T., 1998. Deletion of the alternative sigma factor sigmaB in Staphylococcus aureus reveals its function as a global regulator of virulence genes. J. Bacteriol. 180, 4814-4820.

Kuntumalla, S., Zhang, Q., Braisted, J.C., Fleischmann, R.D., Peterson, S.N., Donohue-Rolfe, A., Tzipori, S., Pieper, R., 2011. In vivo versus in vitro protein abundance analysis of Shigella dysenteriae type 1 reveals changes in the expression of proteins involved in virulence, stress and energy metabolism. BMC Microbiol. 11, 147.

Lammers, A., Kruijt, E., van de, K.C., Nuijten, P.J., Smith, H.E., 2000. Identification of Staphylococcus aureus genes expressed during growth in milk: a useful model for selection of genes important in bovine mastitis? Microbiology 146 (Pt 4), 981-987.

Le Maréchal, C., Hernandez, D., Schrenzel, J., Even, S., Berkova, N., Thiery, R., Vautor, E., Fitzgerald, J.R., Francois, P., Le Loir, Y., 2011a. Genome sequences of two Staphylococcus aureus ovine strains that induce severe (strain 011) and mild (strain 046) mastitis. J. Bacteriol. 193, 2353-2354.

Le Maréchal, C., Jan, G., Even, S., McCulloch, J.A., Azevedo, V., Thiery, R., Vautor, E., Le Loir, Y., 2009. Development of serological proteome analysis of mastitis by Staphylococcus aureus in ewes. J. Microbiol. Methods 79, 131-136.

Le Maréchal, C., Seyffert, N., Jardin, J., Hernandez, D., Jan, G., Rault, L., Azevedo, V., Francois, P., Schrenzel, J., van de Guchte, M., Even, S., Berkova, N., Thiery, R., Fitzgerald, J.R., Vautor, E., Le Loir, Y., 2011b. Molecular basis of virulence in Staphylococcus aureus mastitis. PLoS ONE 6, e27354.

Le Maréchal, C., Thiery, R., Vautor, E., Le Loir, Y., 2011c. Mastitis impact on technological properties of milk and quality of milk products - a review. Dairy Sci. Technol. 91, 247-282.

Le Maréchal, C., Jardin, J., Jan, G., Even, S., Pulido, C., Guibert, J.-M., Hernandez, D., Francois, P., Schrenzel, J., Demon, D., Meyer, E., Berkova, N., Thiery, R., Vautor, E., Le Loir, Y., 2011d. Staphylococcus aureus seroproteomes discriminate ruminant isolates causing mild or severe mastitis. Vet. Res. 42, 35-55.

Mamo, W., Froman, G., 1994a. Adhesion of Staphylococcus aureus to bovine mammary epithelial cells induced by growth in milk whey. Microbiol. Immunol. 38, 305-308.

Mamo, W., Froman, G., 1994b. In vivo-like antigenic surface properties of Staphylococcus aureus from bovine mastitis induced upon growth in milk whey. Microbiol. Immunol. 38, 801-804.

Mamo, W., Lindahl, M., Jonsson, P., 1991a. Enhanced virulence of Staphylococcus aureus from bovine mastitis induced by growth in milk whey. Vet. Microbiol. 27, 371-384.

Mamo, W., Sandgren, C.H., Lindahl, M., Jonsson, P., 1991b. Induction of anti-phagocytic surface properties of Staphylococcus aureus from bovine mastitis by growth in milk whey. Zentralbl. Veterinarmed. B 38, 401-410.

Mayer, S.J., Waterman, A.E., Keen, P.M., Craven, N., Bourne, F.J., 1988. Oxygen concentration in milk of healthy and mastitic cows and implications of low oxygen tension for the killing of Staphylococcus aureus by bovine neutrophils. J. Dairy Res. 55, 513-519.

Pancholi, V., Chhatwal, G.S., 2003. Housekeeping enzymes as virulence factors for pathogens. Int. J. Med. Microbiol. 293, 391-401. 
Rainard, P., 2007. Staphylococcus aureus leucotoxin LukM/F' is secreted and stimulates neutralising antibody response in the course of intramammary infection. Vet. Res. 38, 685-696.

Sengupta, N., Alam, S., 2011. In vivo studies of Clostridium perfringens in mouse gas gangrene model. Curr. Microbiol. 62, 999-1008.

Stenz, L., Francois, P., Whiteson, K., Wolz, C., Linder, P., Schrenzel, J., 2011. The CodY pleiotropic repressor controls virulence in gram-positive pathogens. FEMS Immunol. Med. Microbiol. 62, 123-139.
Tedeschi, G., Taverna, F., Negri, A., Piccinini, R., Nonnis, S., Ronchi, S., Zecconi, A., 2009. Serological proteome analysis of Staphylococcus aureus isolated from sub-clinical mastitis. Vet. Microbiol. 134, 388391.

Vautor, E., Cockfield, J., Le Maréchal, C., Le Loir, Y., Chevalier, M., Robinson, D.A., Thiery, R., Lindsay, J., 2009. Difference in virulence between Staphylococcus aureus isolates causing gangrenous mastitis versus subclinical mastitis in a dairy sheep flock. Vet. Res. 40, 56. 